\title{
Akad Murakkab dalam Produk Keuangan Syariah
}

\author{
Siti Kholijah \\ Sekolah Tinggi Agama Islam Negeri Mandailing Natal \\ Email: lijahhasby@gmail.com
}

\begin{abstract}
The most important thing for creating sharia banking and financial products in addressing the demands of modern society is the development of multiple agreement.The form of a single agreement is not able to respond to contemporary financial transactions. Multiple agreement method should be superior in product development. Agreement in sharia transaction are modified from the exciting agreements in which such agreements are found in almost all sharia product. Multiple Agreement(al-Uqud al-Murakkabah) is one of contempory in Islamic banking whose implementation develops in line with business developments.
\end{abstract}

Keywords : financial and Islamic economymultiple agreement

Abstrak : Hal terpenting untuk menciptakan produk perbankan dan keuangan syariah dalam memenuhi tuntutan kebutuhan masyarakat modern adalah pengembangan multi akad. Bentuk akad tunggal sudah tidak mampu meresponi transaksi keuangan kontemporer. Metode multi akad seharusnya menjadi unggulan dalam pengembangan produk. Akad dalam transaksi syariah diubah dari akad yang biasa menjadimenarik di mana akad tersebut ditemukan di hampir semua produk syariah. AkadMurakkab atau multi akad (al-Uqud al-Murakkabah) adalah salah satu contoh di perbankan syariah yang implementasinya berkembang sejalan dengan perkembangan bisnis.

Kata kunci : Akad Murakkab, produk keuangan syariah

\section{A. Pendahuluan}

Islam disyariatkan untuk memberikan kemaslahatan bagi seluruh alam. Kemaslahatan manusia yang dijaga oleh Islam salah satunya kebutuhan akan harta. Secara absolut harta hanya milik Allah, manusia hanya berhak untuk memanfaatkannya saja dengan cara-cara yang sudah Allah tetapkan. ${ }^{1}$

Hadirnya perbankan salah satu lembaga yang menjadi sarana bagi kebutuhan masyarakat. Perkembangan produk keuangan syariah mengalami kemajuan yang sangat pesat dan menghadapi tantangan yang semakin kompleks. Sehingga, perbankan dan lembaga keuangan syariah harus bisa memenuhi dan menyediakan produk-produk inovatif serta pelayanan yang semakin baik. Salah satu hal penting untuk menciptakan produk perbankan dan keuangan syariah dalam memenuhi kebutuhan masyarakat adalah terwujudnya akad murakkab ini. Karna bentuk akad tunggal sudah tidak mampu lagi merespon transaksi keuangan kontemporer yang terus berkembang dengan cepat.

\footnotetext{
${ }^{1}$ Miti Yarmunida et al., "Penetapan Nisbah Bagi Hasil Pada Akad Kerjasama Pemeliharaan Hewan Ternak Perspektif Ekonomi Syariah,” Jurnal BAABU AL-ILMI: Ekonomi dan Perbankan Syariah 1, no. 1 (2016): 6987, https://ejournal.iainbengkulu.ac.id/index.php/alilmi/article/view/851/727.
} 
Salah satu indikator kemajuan perbankan syariah adalah kemampuan menghasilkan produk- produk keuangan yang mampu bersaing di pasaran nasional bahkan internasional. Para ekonom memandang produk perbankan syariah yang ada hari ini masih belum mampu bersaing. Bahkan sebagian terkesan meng-copy-paste produkproduk konvensional. Padahal di dalam Islam banyak sekali komponen akad yang bisa diformulasikan untuk menghasilkan produk yang tidak kalah menarik dengan produkproduk konvensional. Gabungan akad-akad tunggal yang membentuk formula akad baru inilah yang dikenal dengan nama Al-Uqud Al-Maliyah Al-Murakkabah. ${ }^{2}$

Namun, dalam teori ekonomi Islam klasik bahwa tidak dibenarkan dalam satu transaksi ada dua akad, bila dikembangkan teori ini, maka ekonomi syariah tidak akan berkembang dengan baik.

Oleh karena itu, Perkembangan perekonomian Islam ini sudah mulai menciptakan produk-produk baru yang menjadi daya tarik tersendiri bagi para konsumennya dalam menjawab tantangan modren saat ini. Seperti munculnya produk baru keuangan syariah yang menggunakan system akad murakkab yang digunakan dalam produk keuangan tersebut.Sehingga, dalam hal ini perlu dibahas mengenai akad tersebut. penulis akan membahas tentang pengertian akad murakkab dan berbagai bentuknya,perdebatan seputar akad murakkab dalam kajian fiqh dan potensi pengembangannya dalam keuangan dan ekonomi Islam.

\section{B. Metode Penelitian}

Penelitian ini merupakan jenis penelitian kualitatif ${ }^{3}$ dan kepustakaan dengan fokus kajian pada pandangan fiqh yang berhubungan dengan akad murakkab dan konstruksi akad murakkab dalam lembaga keuangan syariah.Lembaga keuangan syariah yang menjadi fokus dalam penelitian ini adalah produk bank syariah yang menggunakan kombinasi akad.

Sumber data primer diperoleh dengan metode kepustakaan untuk menjawab filosofi model akad murakkab dalam produk keuangan syariah. Sumber data primer juga diperoleh dengan metode wawancara dan observasi untuk menjawab konstruksi hybrid contract model dalam lembaga keuangan syariah, khususnya bank syariah.Wawancara dan observasi dilakukan pada bank syariah diwilayah Panyabungan meliputi Bank Mandiri Syariah. Purposive representative sample digunakan untuk mendukung metode wawancara dengan alasan kompetensi fungsionaris bank yang bersedia dan mampu memberikan informasi untuk penelitian ini.

Sumber data sekunder diperoleh dengan survey literatur dokumentatif, seperti buku, jurnal, publikasi internet, baik internal lembaga keuangan syariah (laporan, leafleat dan sebagainya), maupun eksternal sebagai bahan bacaan. Oleh karena penelitian ini merupakan penelitian pustaka yang ditunjang dengan informasi dari pihak yang kompeten dibidangnya.

\footnotetext{
${ }^{2}$ Haryono Haryono, "Dinamika Dan Solusi Pengembangan Multi Akad (Hybrid Contract) Sebagai Basis Produk Perbankan Syariah,” Ad Deenar: Jurnal Ekonomi dan Bisnis Islam 3, no. 01 (2019): 17-36.

${ }^{3}$ Lexy j Moleong, Metodologi Penelitian Kualitatif (Bandung: PT. Remaja. Rosdakarya, 2006). h. 2-6
} 


\section{Hasil dan Pembahasan}

\section{Pengertian Akad}

Menurut bahasa akad memiliki beberapa arti, yakni diantaranya adalah mengikat

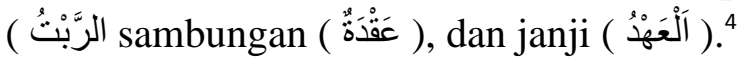

Seperti terdapat dalam surah Ali-Imran ayat 76 :

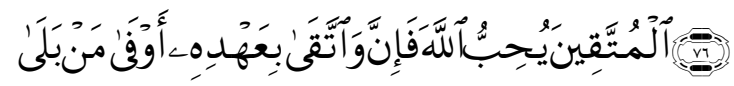

Artinya: (Bukan demikian), sebenarnya siapa yang menepati janji (yang dibuatNya) dan bertakwa, Maka Sesungguhnya Allah menyukai orang-orang yangbertakwa. (Q.S. Ali Imran: 76). ${ }^{5}$

Akad atau kontrak berasal dari bahasa Arab yang berarti ikatan atau simpulan, baik ikatan yang nampak (hissy) maupun yang tidak nampak (ma'nawi). Subhi Mahmassaniy mengartikan akad sebagai ikatan atau hubungan di antara ijab dan qabul yang memiliki akibat hukum terhadap hal-hal yang dikontrakkan. ${ }^{6}$

Pengertian akad yang disampaikan oleh Subhi Mahmassaniy merupakan pengertian yang masih umum, sedangkan menurut para ahli hukum Islam atau mayoritas ulama, akad adalah pertalian antara ijab dan qabul yang dibenarkan oleh syara'yang menimbulkan akibat hukum terhadap objeknya. ${ }^{7}$

Sedangkan kata al-murakkabah (murakkab) secara etimologi berarti al-jam'u (mashdar), yang berarti pengumpulan atau penghimpunan. Kata murakkab sendiri berasal dari kata "rakkaba-yurakkibu-tarkiban" yang mengandung arti meletakkan sesuatu pada sesuatu yang lain sehingga menumpuk, ada yang di atas dan yang di bawah. Sedangkan murakkab menurut pengertian para ulama fiqh adalah himpunan beberapa hal sehingga disebut dengan satu nama. Seseorang menjadikan beberapa hal menjadi satu hal (satu nama) dikatakan sebagai melakukan penggabungan (tarkib), sesuatu yang dibuat dari dua atau beberapa bagian, sebagai kebalikan dari sesuatu yang sederhana (tunggal/basith) yang tidak memiliki bagian-bagian dan meletakkan sesuatu di atas sesuatu lain atau menggabungkan sesuatu dengan yang lainnya. ${ }^{8}$

Dengan demikian pengertian hybrid contract atau al-'uqud al-murakkabah dalam istilah ada beberapa pengertian dari kalangan cendikiawan muslim di antaranya menurut Nazih Hammad, akad murakkab adalah kesepakatan dua pihak untuk melaksanakan suatu akad yang mengandung dua akad atau lebih, seperti jual beli dengan sewa menyewa, hibah, wakalah, qardh, muzara'ah, sharf (penukaran mata uang), syirkah, mudharabah, dan seterusnya sehingga semua akibat hukum akad-akad yang terhimpun tersebut, serta semua hak dan kewajiban yang ditimbulkannya dipandang sebagai satu kesatuan yang tidak dapat dipisah-pisahkan, sebagaimana akibat hukum dari satu akad. Sedangkan Al-Imrani dalam jurnal Muhammad Iman Sastra Mihajat, mendefinisikan hybrid contract yaitu kesepakatan

\footnotetext{
${ }^{4}$ Hendi Suhendi, Fiqih Muamalah (Jakarta: PT. Raja Grofindo Persada, 2013).h. 44-45

${ }^{5}$ Departemen RI, Al-Qur'an Dan Terjemahannya (Jakarta: Darus Sunnah, 2002). h. 143

${ }^{6}$ Rahmani Timorita Yulianti, “Asas-Asas Perjanjian (Akad) Dalam Hukum Kontrak Syari'ah,”La_Riba 2, no. 1 (2008): 91-107.

${ }^{7}$ Yeni Salma Barlianti Gemala Dewi, Wirdyaningsih, Hukum Perikatan Islam Di Indonesia (Jakarta: Prenada Media, 2005). h. 45-46

${ }^{8}$ Najamuddin, “Al-’Uqûd Al-Murakkabah Dalam Perspektif Ekonomi Syariah,” Syari'ah 2, no. 2 (2013): $5-17$.
} 
dua pihak untuk melaksanakan suatu akad yang mengandung dua akad atau lebih. Semua akibat hukum akad-akad yang terhimpun tersebut, serta semua hak dan kewajiban yang ditimbulkannya dipandang sebagai kesatuan yang tidak dapat dipisah-pisahkan, sebagaimana akibat hukum dari satu akad. Saat ini hybrid contract atau multi akad sangat banyak dipraktikkan dalam transaksi pada lembaga keuangan syariah seperti perbankan dan asuransi. Maraknya penggunaan akad berganda dalam transaksi lembaga keuangan syariah saat ini tidak terlepas dari legalitas multi akad yang terdapat dalam fatwa Dewan Syariah Nasional - Majelis Ulama Indonesia (Fatwa DSN MUI), sebagai salah satu landasan operasional lembaga keuangan syariah di Indonesia. ${ }^{9}$

\section{2. $\quad$ Bentuk-Bentuk Akad Murakkab}

Adapun bentuk-bentuk hybrid contract (multiakad) atau akad murakkab, menurut Al-Imrani dalam jurnal Ali Amin Isfandiar terbagi dalam lima macam, yaitu: ${ }^{10}$ pertama, akad bergantung/ Akad bersyarat (al-uqud al-mutaqabilah). Taqabul menurut bahasa berarti berhadapan. Al-uqud al-mutaqabilah adalah multiakad dalam bentuk kedua merespon akad pertama, di mana kesempurnaan akad pertama bergantung pada sempurnannya akad kedua melalui proses timbal balik atau akad satu bergantung dengan akad lainnya. Model akad seperti ini sudah dikenal lama dan praktiknya sudah banyak. Banyak ulama telah membahas tema ini, baik yang berkaitan dengan hukumnya, atau model pertukarannya, misalnya antara akad pertukaran (mu'awadhah) dengan akad tabarru', antara tabarru' dengan akad tabarru' atau akad pertukaran dengan akad pertukaran.

Kedua, Akad terkumpul (al-uqud al-mujtami'ah). Al-uqud al-mujtami'ahadalah multiakad yang terhimpun dalam satu akad. Dua atau lebih akad terhimpun menjadi satu akad. Multiakad yang mujtami'ah ini dapat terjadi dengan terhimpunnya dua akad yang memiliki akibat hukum berbeda di dalam satu akad terhadap dua objek dengan satu harga, dua akad berbeda akibat hukum dalam satu akad terhadap dua objek dengan dua harga, atau dua akad dalam satu akad yang berbeda hukum atas satu objek dengan satu imbalan, baik dalam waktu yang sama atau waktu yang berbeda.

Ketiga, Akad berlawanan (al-uqud al-mutanaqidhah wa al mutadhadah wa almutanafiyah). Ketiga istilahal-mutanaqidhah, al-mutadhadah, al-mutanafiyah memiliki kesamaan bahwa ketiganya mengandung maksud adanya perbedaan. Tetapi ketiga istilah ini mengandung implikasi yang berbeda.Mutanaqidhah artinya berlawanan, seperti pada contoh seseorang berkata sesuatu lalu berkata sesuatu lagi yang berlawanan dengan yang pertama. Mutadhadah adalah dua hal yang tidak mungkin terhimpun dalam satu waktu, seperti antara malam dan siang. Sedangkan arti mutanafiyah adalah menafikan, lawan dari menetapkan.

Dari pengertian ini, para ahli fiqih merumuskan maksud dari multiakad yaitu satu hal dengan satu nama tidak cocok untuk dua hal yang berlawanan, maka setiap

\footnotetext{
${ }^{9}$ Muhammad Iman Sastra Mihajat, "Hybrid Contract In Islamic Banking and Finance : A Proposed Shariah Principles and Parameters for Product Development," EBJM - Special Issue: Islamic Management and Business 2, no. 2 (2014): 89-100.

${ }^{10}$ Ali Amin Isfandiar, “Analisis Fiqh Muamalah Tentang Hybrid Contract Model dan Penerapannya Pada Lembaga Keuangan Syariah," Jurnal Penelitian 10, no. 2 (March 26, 2014), http://ejournal.iainpekalongan.ac.id/index.php/Penelitian/article/view/361/570.
} 
dua akad yang berlawanan tidak mungkin dipersatukan dalam satu akad; Satu hal dengan satu nama tidak cocok untuk dua hal yang berlawanan, karena dua sebab yang saling menafikan akan menimbulkan akibat yang saling menafikan pula; Dua akad yang secara praktik berlawanan dan secara akibat hukum bertolak belakang tidak boleh terhimpun; Haram terhimpunnya akad jual beli dan sharf dalam satu akad. Mayoritas ulama Maliki berpendapat akad batal karena alasan ketentuan hukum kedua akad itu saling menafikan, yaitu bolehnya penundaan dan khiyar dalam jual beli, sedangkan dalam sharf, penundaan dan khiyar tidak boleh; Ada dua pendapat mengenai terhimpunya jual beli dan ijarah, dan jual beli dengan sharf dengan satu imbalan. Pertama mengatakan kedua akad batal karena hukum dua akad berlawanan dan tidak ada prioritas satu akad atas yang lain karenanya kedua akad tidak sah. Pendapat kedua mengatakan, sah kedua akad dan imbalan dibagi untuk dua akad sesuai dengan harga masing-masing objek akad. Penggabungan ini tidak membatalkan akad; Terhimpunnya dua akad atas objek yang memiliki harga berbeda dengan satu imbalan, seperti sharf dan bai' atau menjual barang yang dinyatakan bahwa akad telah mengikat sebelum serah terima, hukumnya sah, karena keduanya dapat dimintakan imbalan sebagai harga masing-masing.

Keempat, Akad berbeda (al-uqud al mukhtalifah). Adapun yang dimaksud dengan akad yang mukhtalifahadalah terhimpunnya dua akad atau lebih yang memilki perbedaan semua akibat hukum di antara kedua akad itu. Seperti perbedaan akibat hukum dalam akad jual beli dan sewa, dalam akad sewa diharuskan ada ketentuan waktu, sedangkan dalam jual beli sebaliknya. Contoh lain, akad ijarah dan salam. Dalam salam harga salam harus diserahkan pada saat akad, sedangkan dalam ijarah, harga sewa tidak harus diserahkan pada saat akad.

Kelima, Akad sejenis (al-uqud al mutajanisah). Akad mutajanisah yaitu akadakad yang mungkin dihimpun dalam satu akad, dengan tidak mempengaruhi di dalam hukum dan akibat hukumnya. Multiakad jenis ini dapat terdiri dari satu jenis akad seperti akad jual beli dan sewa menyewa. Multiakad jenis ini dapat pula terbentuk dari dua akad yang memilki hukum yang sama atau berbeda.

\section{Perdebatan Seputar Akad Murakkab(Multi Akad) dalam Kajian Fiqh}

Sejarah dibentuknya lembaga keuangan syariah di Indonesia, diharapkan mampu menjembatani kebutuhan akan penerapan ekonomi Islam bagi sebagian besar umat Islam yang ada di Indonesia.Dengan semakin berkembangnya produk-produk yang dikeluarkan lembaga keuangan syariah termasuk semakin banyaknya produk yang menggunakan multi akad sehingga memerlukan kajian bagaimana kedudukan ataupun status hukum dari multi akad dalam hukum Islam.

Persoalan akad murakkab atau hybrid contract berkembang dari teori bahwa syariah tidak membolehkan dua akad dalam satu transaksi akad (two in one). Padahal, larangan two in one terbatas dalam tiga kasus saja sesuai dengan hadis Nabi Muhammad Saw yang terkait dengan larangan penggunaan hybrid contract. Ketiga hadis itu berisi tiga larangan, pertama larangan bay' dan salaf, kedua, larangan bai'ataini fi bai'atin, dan ketiga larangan shafqataini $f i$ shafqatin. ${ }^{11}$ Meski ada multiakad yang diharamkan, namun prinsip dari multiakad ini adalah boleh dan hukum dari multi akad diqiyaskan dengan hukum akad yang membangunnya.

\footnotetext{
${ }^{11}$ Ibid. h. 217.
} 
Artinya, setiap muamalat yang menghimpun beberapa akad, hukumnya halal selama akad-akad yang mendasarinya adalah boleh. Ketentuan ini memberi peluang pada pembuatan model transaksi yang mengandung multi akad.

Mengenai status hukum akad murakkab atau multi akad, Adapun mengenai status hukum multiakad, ulama berbeda pendapat terutama berkaitan dengan hukum asalnya. Perbedaan ini menyangkut apakah multiakad sah dan diperbolehkan atau batal dan dilarang untuk dipraktikkan. Mengenai hal ini ulama berada dalam dua pendapat tersebut; membolehkan dan melarang. Mayoritas ulama Hanafiyah, sebagian pendapat ulama Malikiyah, ulama Syafi'iyah, dan Hanbali berpendapat bahwa hukum multiakad sah dan diperbolehkan menurut syariat Islam. Bagi yang membolehkan beralasan bahwa hukum asal dari akad adalah boleh dan sah, tidak diharamkan dan dibatalkan selama tidak ada dalil hukum yang mengharamkan atau membatalkannya. ${ }^{12}$

Para ulama yang membolehkan praktik multi akad bukan berarti membolehkan secara bebas, tetapi ada batasan yang tidak boleh dilewati. Karena batasan ini akan menyebabkan multiakad menjadi dilarang. Dikalangan ulama, batasan-batasan ini ada yang disepakati dan diperselisihkan.

Dari sisi relevansi dengan kebutuhan zaman, pembaruan dan penemuan akad mutlak dibutuhkan. Perkembangan modern membuktikan bahwa banyak praktik muamalah dan transaksi keuangan yang belum pernah dipraktikkan pada masa Nabi dan tidak disebutkan secara jelas hukumnya dalam agama. Kebutuhan akad transaksi baru menjadi sebuah keniscayaan seiring dengan pertumbuhan manusia dan perkembangan ilmu dan teknologi. Kalangan Malikiyah dan Ibn Taimiyah berpendapat bahwa multiakad merupakan jalan keluar dan kemudahan yang diperbolehkan dan disyariatkan selama mengandung manfaat dan tidak dilarang agama. Karena hukum asalnya adalah sahnya syarat untuk semua akad selama tidak bertentangan dengan agama dan bermanfaat bagi manusia. ${ }^{13}$

Dari paparan di atas, dapat diambil kesimpulan melalui metode muqâranah dan tarjîh bahwa pendapat pertama lebih kuat dan sesuai dengan perkembangan zaman dibanding dengan pendapat kedua. Kesimpulan ini didasarkan atas beberapa pertimbangan ${ }^{14}$ :

1. Dalil yang digunakan pendapat pertama memiliki status yang kuat dan kejelasan makna yang dikandungnya.

2. Kesesuaian dengan tujuan syariah (maqâshid syarîah), yaitu adanya kemudahan dalam muamalah, keringanan dalam beban, dan memberi peluang inovasi.

3. Relevansi dengan perkembangan zaman dan kebutuhan manusia akan transaksi dan akad-akad modern.

Kebolehan multiakad yang didasarkan atas prinsip hukum asal dari akad adalah boleh dan hukum multiakad diqiyaskan dengan hukum akad-akad yang membangunnya, harus memperhatikan ketentuan-ketentuan agama yang membatasinya. Artinya, meskipun multiakad diperbolehkan, ada batasan-batasan yang tidak boleh dilanggar, karena batasan itu menjadi rambu bagi multiakad agar tidak terjerumus kepada praktik muamalah yang diharamkan. Batasan-

\footnotetext{
${ }^{12}$ Nazîh Hammâd, Al-'uqûd Al-Murakkabah Fî Al-Fiqh Al-Islâmy (Damaskus: Dâr al-Qalam, 2005). h. $11-12$.

13 Isfandiar, "ANALISIS FIQH MUAMALAH TENTANG HYBRID CONTRACT MODEL DAN PENERAPANNYA PADA LEMBAGA KEUANGAN SYARIAH.” h. 218

${ }^{14}$ Hammâd, Al-'uqûd Al-Murakkabah Fî Al-Fiqh Al-Islâmy. h. 74-75
} 
batasan sebagaimana dijelaskan pada bagian sebelumnya adalah garis batas bagi praktik multiakad yang tidak boleh dilewati. ${ }^{15}$

\section{Potensi Pengembangan Akad Murakkab(Multi Akad) dalam Keuangan Syariah}

Pada masa kini di mana transaksi keuangan modern semakin kompleks, dibutuhkan model kontrak dalam bentuk kombinasi beberapa akad yang disebut dengan akad murakkab atau multi akad. Kombinasi akad pada masa kini adalah sebuah keniscayaan, akad murakkab ini dikembangkan dalam merespon keuangan kontemporer.

Dalam hal ini produk lembaga keuangan syariah khususnya yang menggunakan multi akad atau akad murakkab akan sangat besar potensinya jika SDM dan produk tersebut memenuhi kebutuhan masyarakat tetapi tentunya harus disesuaikan dengan syariat.Lembaga keuangan syariah dituntut melakukan penciptaan berbagai produk, regulator membuat regulasi yang mengatur dan mengawasi produk yang ditawarkan dan laksanakan oleh praktisi dan akademisi pun dituntut memberikan tuntunan agar produk maupun regulasi tidak menyimpang dari prinsip-prinsip syariah. Sehingga, dalam rangka memenuhi kebutuhan masyarakat, para lembaga keuangan syariah melakukan berbagai upaya untuk meciptakan produk-produk baru atau bahkan banyak melakukan adaptasi dan menjadikannya syariah terhadap

produk-produk lama (konvensional).Terdapat keterkaitan yang kuat antara inovasi produk dengan pengembangan pasar produkbank syariah.

Salah satu parameter untuk menilai suatu produk apakah telah memenuhi prinsip syariah atau tidak adalah dengan memperhatikan akad-akad dan berbagai ketentuannyayangdigunakandalamproduktersebut.Produk-produkdalamkegiatan keuangan syariah, jika terhadapnya dilakukan al-takyif al-fiqi, beberapa atau bahkan sebagian terbesar ternyata mengandung beberapa akad. Sebagai contoh, dalam transaksi kartu kredit syariah terdapat akad ijarah, qardh, dan kafalah; obligasi syariah mengandung sekurang-kurangnya akad mudharabah (atau ijarah) dan wakalah,sertaterkadangdisertaikafalahatauwa'd;IslamicSwapmengandung Beberapa kali akad tawarruq, bai', wakalah, sharf dan terkadang atau selalu disertai wa'd, dana talangan haji mengandung akad ijarah dan qard. Dalam setiap transaksi, akadakad tersebut dilakukan secara bersamaan atau setidak-tidaknya setiap akad yang terdapat dalam suatu produk tidak bisa ditinggalkan, karena kesemuanya merupakan satu kesatuan. Transaksi seperti itulah yangdalam tulisan ini diistilahkan dengan "Multi Akad" yang kini dalam peristilahan fiqh muamalat kontemporer (fiqh almu'amalat al-maliyah al-mu'ashirah) disebut dengan al-'uqudal-murakkabah. ${ }^{16}$

Menurut Mabid Al-Jarhi, mantan Direktur Islamic Development Bank (IDB), bahwa kombinasi akad di zaman sekarang adalah sebuah keniscayaan. Namun persoalan yang dihadapi adalah, literatur ekonomi syariah yang ada di Indonesia, khususnya, sudah lama mengembangkan teori bahwa syariah tidak membolehkan dua akad dalam satu transaksi akad (two in one). Padahal, larangan two in one hanya mengenai tiga kasus saja yang disebutkan dalam hadis yang berkaitan dengan larangan penggunaan akad Murakkab atau hybrid contract. Ketiga kasus yang

15 Isfandiar, "ANALISIS FIQH MUAMALAH TENTANG HYBRID CONTRACT MODEL DAN PENERAPANNYA PADA LEMBAGA KEUANGAN SYARIAH.” h. 224.

${ }^{16}$ Hasanudin Maulana, "Multiakad Dalam Transaksi Syariah Kontemporer Pada Lembaga Keuangan Syariah Di Indonesia," Al-Iqtishad: Journal of Islamic Economics 3, no. 1 (2016). 
disebutkan dalam hadis itu berisi tentang tiga larangan, yaitu (1) larangan bai'ataini fi bai'atin; (2), larangan shafqataini fi shafqatin, dan (3) larangan bay' dan salaf (Agustianto, t.t.). Ketiga hadis itulah yang selalu dijadikan rujukan para ahli, konsultan dan banker syariah tentang larangan akad two in one dalam satu transaksi. Namun, larangan itu hanya berlaku pada kasus-kasus tertentu. Bahkan hadis pertama (bai'ataini fi bai'atin) dan kedua (shafqataini fi shafqatin) maknanya sama, meski redaksinya berbeda. Maksud Hadis shafqataini fi shafqatin adalah bay'ataini $f i$ bay'atin. Two in one tidak boleh diperluas kepada masalah lain yang tidak relevan dan tidak pas konteksnya. Sayangnya, larangan tersebut digenerasilisasi untuk semua kontrak, sehingga setiap kontrak yang mengandung dua akad atau lebih dipandang bertentangan dengan syariah. ${ }^{17}$

Dari sisi relevansi dengan kebutuhan zaman, Produk-produk dala perbankan syariah, beberapa atau bahkan sebagian terbesar ternyata mengandung beberapa akad. Sebagai contoh, dalam transaksi kartu kredit syariah terdapat akad ijarah, qardh, dan kafalah, obligasi syariah mengandung sekurang-kurangnya akad mudharabah (atau ijarah) dan wakalah, serta terkadang disertai kafalah. Dalam setiap transaksi, akad-akad tersebut dilakukan secara bersamaan atau setidaktidaknya setiap akad yang terdapat dalam suatu produk tidak bisa ditinggalkan, karena semuanya merupakan satu kesatuan dan merupakan transaksi yang menggunakan akad murakkab.

Berikut contoh beberapa transaksi akad murakkab dalam produk keuangan Syariah:

\section{a. Akad Murakkab atau Hybrid Contract dalam IMBT}

Ijarah al- muntahiyah bi al-tamlik (IMBT) merupakan salah satu contoh hasil konstruksi penghilangan kebathilan produk leasing pada industri keuangan konvensional. Akad al-ijarah al- muntahiyah bi al-tamlik (IMBT) merupakan kombinasi antara akad sewa (ijarah) dengan hak opsional jual beli atau hibah di akhir masa sewa yang sifatnya tidak mengikat. Meski terjadi perbedaan pendapat apakah IMBT termasuk kedalam akad gabungan (murakkab) yang dilarang oleh Nabi atau bukan, namun mayoritas ulama sepakat untuk memperbolehkan praktik akad/perjanjian IMBT. ${ }^{18}$

Ketentuan tentang IMBT adalah berikut: Pihak yang melakukan al-ijarah almuntahiyah bi al-tamlik harus melaksanakan akad ijarah terlebih dahulu. Akad pemindahan kepemilikan, baik dengan jual beli atau pemberian, hanya dapat dilakukan setelah masa ijarah selesai. Janji pemindahan kepemilikan yang disepakati di awal akad ijarah adalah wa'd, yang hukumnya tidak mengikat. Apabila janji itu ingin dilaksanakan, maka harus ada akad pemindahan kepemilikan yang dilakukan ${ }^{19}$ setelah masa ijarah selesai. Jika salah satu pihak tidak menunaikan kewajibannya atau jika terjadi perselisihan di antara kedua belah pihak,

\footnotetext{
${ }^{17}$ Isfandiar, “Analisis Fiqh Muamalah Tentang Hybrid Contract Model Dan Penerapannya Pada Lembaga Keuangan Syariah.” h. 206.

${ }^{18}$ Nasrulloh Ali Munif, “Analisis Akad Ijarah Muntahiya Bittamlik Dalam Perspektif Hukum Islam Dan Hukum Postif DI Indonesia," Ahkam: Jurnal Hukum Islam 4, no. 1 (July 1, 2016), http://ejournal.iaintulungagung.ac.id/index.php/ahkam/article/view/329. h. 78

${ }_{19}$ Dewan Syariah Nasional MUI. Fatwa Dewan Syariah Nasional MUI No. 27/DSN-MUI/III/2002 Tentang Al-Ijarah Al-Muntahiyah Bi Al-Tamlik.
} 
maka penyelesaiannya dilakukan melalui Badan Arbitrasi Syari'ah setelah tidak tercapai kesepakatan melalui musyawarah.

\section{b. Akad Murakkab dalam Syariah Card}

Syariah Card adalah fasilitas kartu talangan yang dipergunakan oleh pemegang kartu sebagai alat bayar atau pengambilan uang tunai pada tempat-tempat tertentu yang harus dibayar lunas kepada pihak yang memberikan talangan pada waktu yang telah ditetapkan. Jadi, syariah card dapat diartikan sebagai kartu yang berfungsi seperti kartu kredit yang hukumnya berdasarkan prinsip syariah. Syariah card merupakan hasil konstruksi menghilangkan kebathilan produk kartu kredit pada perbankan konvensional.

Terdapat tiga ketentuan akad yang digunakan dalam produk syariah card ini, yaitu sebagai berikut: Pertama, akad kafalah. Akad inidigunakan antara penerbit kartu dengan merchant. Dalam hal ini penerbit kartu adalahpenjamin (kafil) bagi pemegang kartu terhadap merchant atas semua kewajiban bayar (dayn)yang timbul dari transaksi antara pemegang kartu dengan merchant, dan/atau penarikantunai dari selain bank atau ATM bank penerbit kartu. Atas pemberian kafalah, penerbit kartu dapat menerima ujrah kafalah .

Kedua, akad qardh. Akad ini digunakan antara penerbit kartu dengan pemegang kartu. Dalam hal ini penerbit kartu adalah pemberi pinjaman (muqridh) kepada pemegangkartu (muqtaridh) melalui penarikan tunai dari bank atau ATM bank penerbit kartu. Ketiga, akad ijarah. Akad ini digunakan antara penerbit kartu dengan pemegangkartu. Dalam hal ini penerbit kartu adalah penyedia jasa sistem pembayaran dan pelayananterhadap pemegang kartu. Atas ijarah ini, pemegang kartu dikenakan membership fee. ${ }^{20}$

\section{c. Akad Murakkab dalam Pembiayaan Properti (Musyarakah Mutanaqishah /MMQ)}

Pembiayaan properti MMQ merupakan salah satu contoh hasil konstruksi syariah dalam menghilangkan transaksi riba pada kredit usaha di bank konvensional. Musyarakah Mutanaqishah (MMQ) atau diminishing partnership merupakan produk turunan dari akad musyarakah atau syirkah. Secara etimologi syirkah berarti percampuran (ikhtilath), yaitu bercampur antara dua hal sehingga sulit membedakan antara keduanya. Apabila air bercampur dengan gula dinamakan syirkah, karena hampir tidak mungkin dipisahkan. Kemudian kata syirkah ini dipakai dalam istilah akad (transaksi) sekalipun tidak terdapat percampuran antara dua hal. Musyarakah atau syirkah adalah adalah kesepakatan antara dua pihak untuk bekerjasama dalam modal dan usaha untuk memperoleh keuntungan, di mana keuntungan tersebut dibagi sesuai dengan kesepakatan. Sementara mutanaqishah berasal dari kata yatanaqishu-tanaqish-tanaqishan- mutanaqishun yang berarti mengurangi secara bertahap. ${ }^{21}$

Musyarakah Mutanaqishah (MMQ) adalah musyarakah atau syirkah yang kepemilikan asset (barang) atau modal salah satu pihak (syarik) berkurang

\footnotetext{
${ }^{20}$ Dewan Syariah Nasional MU. Fatwa Dewan Syari'ah Nasional MUI No. 54/DSN-MUI/X/2006 Tentang Syariah Card.

${ }^{21}$ Aidil Alfin, "Multi Akad Dalam Pespektif Fikih Dan Implementasinya Di Perbankan Syariah," AlHrriyah 16, no. 1 (2015). h. 16
} 
disebabkan pembelian secara bertahap oleh pihak lainnya. Bentuk kerjasama ini berakhir dengan pengalihan hak salah satu pihak kepada pihak lain.Akad MMQ terdiri dari akad musyarakah/ syirkah dan bai' (jual-beli). Dalam akad MMQ, pihak pertama (syarik) wajib berjanji untuk menjual seluruh hishsha hatau bagiannya secara bertahap dan pihak kedua (syarik) wajib membelinya. Jual beli tersebut dilaksanakan sesuai kesepakatan. Setelah selesai pelunasan penjualan, seluruh hishsha Lembaga Keuangan Syariah beralih kepada syarik lainnya (nasabah). ${ }^{22}$

Implementasi MMQ dalam operasional perbankan syariah adalah merupakan kerjasama antara bank syariah dengan nasabah untuk pengadaan atau pembelian suatu barang (benda), di mana asset barang tersebut menjadi milik bersama. Adapun besaran kepemilikan dapat ditentukan sesuai dengan sejumlah modal atau dana yang disertakan dalam kontrak kerjasama tersebut. Selanjutnya nasabah akan membayar (mengangsur) sejumlah modal/dana yang dimiliki oleh bank syariah. Perpindahan kepemilikan dari porsi bank syariah kepada nasabah seiring dengan bertambahnya jumlah modal nasabah dari pertambahan angsuran yang dilakukan nasabah. Dengan kata lain, penurunan porsi kepemilikan bank syariah terhadap barang atau benda berkurang secara proporsional sesuai dengan besarnya angsuran. Hingga angsuran berakhir berarti kepemilikan suatu barang atau benda tersebut sepenuhnya menjadi milik nasabah.

Aset tersebut dapat di-ijarah-kan kepada syarik atau pihak lain. Apabila aset musyarakah menjadi obyek ijarah, maka syarik (nasabah) dapat menyewa aset tersebut dengan nilai ujrah yang disepakati. Keuntungan yang diperoleh dari ujrah tersebut dibagi sesuai dengan nisbah yang telah disepakati dalam akad, sedangkan kerugian harus berdasarkan proporsi kepemilikan. Nisbah keuntungan dapat mengikuti perubahan proporsi kepemilikan sesuai kesepakatan para syarik. Kadar/ukuran bagian/porsi kepemilikan asset musyarakah syarik (LKS) yang berkurang akibat pembayaran oleh syarik (nasabah), harus jelas dan disepakati dalam akad. Biaya perolehan aset musyarakah menjadi beban bersama sedangkan biaya peralihan kepemilikan menjadi beban pembeli.

\section{d. Akad Murakkab dalam Gadai Syariah}

Gadai syariah merupakan hasil konstruksi menghilangkan kebathilan pada pegadaian konvensional. Rahn atau gadai adalah menahan barang sebagai jaminan atas utang. Barang yang ditahan tersebut memiliki nilai ekonomis. Dengan demikan, pihak yang menahan memperoleh jaminan untuk dapat mengambil kembali seluruh atau sebagian piutangnya. ${ }^{23}$ Substansi dalam peristiwa rahn adalah untuk menghindari kemudharatan yang diakibatkan oleh berkhianatnya salah satu pihak atau kedua belah pihak ketika keduanya melakukan transaksi utang piutang. Fungsi barang gadai adalah untuk menjaga kepercayaan masing-masing pihak, sehingga penerima gadai (murtahin) meyakini bahwa pemberi gadai (rahin) beritikad baik untuk mengembalikan pinjamannya (marhun bih) dengan cara menggadaikan barang atau benda yang dimilikinya (marhun), serta tidak melalaikan jangka waktu

${ }^{22}$ Dewan Syariah Nasional MUI. Fatwa Dewan Syariah Nasional MUI No. 73/DSN-MUI/XI/2008 Tentang Musyarakah Mutanaqisah.

${ }^{23}$ Dewan Syariah Nasional MUI. Fatwa Dewan Syariah Nasional MUI No. 31/DSN-MUI/VI/2002 Tentang Pengalihan Utang. 
pengembalian utangnya itu. Pada hakikatnya praktik gadai merupakan salah satu bentuk dari muamalah, dimana sikap tolong menolong dan amanah sangat diutamakan. $^{24}$

Terdapat beberapa alternatif mekanisme aktivitas perjanjian gadai dengan menggunakan tiga akad perjanjian. Tiga akad perjanjian ini tergantung pada tujuan menggadaikan jaminan dilakukan. Ketiga akad tersebut adalah akad al- qardh alhasan, akad mudharabah, dan akad al-bai' muqayyadah. Akad al-qardh al-hasan dilakukan untuk nasabah yang menginginkan menggadaikan barangnya untuk keperluan konsumtif. Dengan demikian rahin akan memberikan biaya upah, atau fee kepada murtahin, karena murtahin telah menjaga atau merawat marhun.

Akad mudharabah diterapkan untuk nasabah yang menginginkan menggadaikan jaminannya untuk menambah modal usaha (pembiayaan investasi atau modal kerja). Dengan demikian rahin akan memberikan bagi hasil kepada murtahin sesuai dengan kesepakatan sampai dengan modal yang dipinjamkan terlunasi. Sementara akad albai' muqayyadah dapat dilakukan jika rahin yang menginginkan menggadaikan barangnya untuk keperluan produktif, artinya dalam menggadaikan barangnya rahin tersebut menginginkan modal kerja berupa pembelian barang. Sedangkan barang jaminan yang dijaminkan untuk akad ini adalah barang-barang yang dapat dimanfaatkan atau tidak dapat dimanfaatkan oleh rahin maupun murtahin. Dengan demikian murtahin akan membelikan barang yang sesuai dengan keinginan rahin dan rahin akan memberikan mark-up kepada murtahin sesuai dengan kesepakatan pada saat akad berlangsung dan sampai batas waktu yang telah ditentukan. ${ }^{25}$

\section{Simpulan}

Dengan dikemukakannya pendapat pendapat ulama mengenai multi akad di atas, umat Islam dalam menjalankan transaksi bisnis baik secara individu maupun dengan lembaga keuangan syariah diharapkan lebih berhati-hati serta mampu menghindari halhal yang haram dan menggantinya dengan yang halal dan tidak semerta merta hanya untuk memenuhi tuntutan pasar atau tuntutan zaman. Harapan untuk memajukan perekonomian umat Islam harus tetap ada, sebagaimana awal mula didirikannya lembaga keuangan syariah di Indonesia dengan semangat memajukan roda perekonomian umat Islam sekaligus menjalankan syariat Islam. ${ }^{26}$ Dari pemaparan di atas disimpulkan bahwa akad murakkab atau multiakad dalam kehidupan sehari-hari tanpa kita sadari dan tanpa kita mengerti bagaimana hukum akad murakkab tersebut kita telah banyak mempraktekkanya. Ada beberapa ulama yang berbeda pendapat mengenai hukum akad murakkab, banyak yang mengkaji dengan berbagai dasar hukum. Akan tetapi, akad murakkab yang membolehkan lebih kuat pendapatnya dari pada para jumhur ulama yang mengharamkannya. Pemberlakuan akad murakkab dalam transaksasi modern adalah sebuah keniscayaan yang tujuannya untuk mengamalkan nilai-nilai syariat yang ada di balik akad tersebut. Ketentuan Sunnah terkait multi akad merupakan sebuah pengecualian

\footnotetext{
${ }^{24}$ Irayana Harpen, "Kajian Akad Pembiayaan Logam Mulia Untuk Masyarakat Pada Pegadaian Syariah,” Menara Riau 13, no. 1 (2014): 39-60.

${ }^{25}$ Arrum Mahmudahningtyas, “Analisis Kesyariahan Transaksi Rahn Emas (Studi pada Pegadaian Syariah Cabang Landungsari Malang”, Jurnal Ilmiah, Fakultas Ekonomi Dan Bisnis, Universitas Brawijaya, Malang, 2015

${ }^{26}$ Putri Muthi'ah Mairo, "Penerapan Multi Akad Pada Beberapa Produk Lembaga Keuangan Syariah Ditinjau Dari Hukum Islam” (Universitas Airlangga, 2013), http://repository.unair.ac.id/36993/.h. 40-41
} 
yang tidak berlaku secara umum. Akad Murakkab ada yang bersifat alamiah hukumnya boleh, misalnya pemberlakuan antara akad pokok seperti al- qardl dengan akad yang bersifat ikutan seperti al-rahn, al-hiwâlah, dan lain-lain.

Sedangkan akad murakkab modifikasi tidak dilarang selama dalam pemberlakuan akad tidak melanggar prinsip sunnah terkait peleburan akad. Berdasarkan kenyataan tersebut, perdebatan fiqh bukan pada tataran multi akadnya yang telah menjadi keniscayaan, melaikan pada tataran cara memodifikasinya. Dapat disimpulkan bahwa keharaman akad murakkab pada dasarnya disebabkan oleh tiga hal: dilarang agama atau hilah karena dapat menimbulkan ketidakpastian (gharar) dan ketidakjelasan, menjerumuskan ke praktik riba, dan akad murakkab yang menimbulkan akibat hukum yang bertentangan pada objek yang sama. Dengan kata lain, akad murakkab yang memenuhi prinsip syariah adalah akad murakkab yang memenuhi standar atau tetap (dhawbith) sebagaimana telah dikemukakan

\section{Daftar Pustaka}

Aidil Alfin. "Multi Akad Dalam Pespektif Fikih Dan Implementasinya Di Perbankan Syariah." Al-Hrriyah 16, no. 1 (2015).

Gemala Dewi, Wirdyaningsih, Yeni Salma Barlianti. Hukum Perikatan Islam Di Indonesia. Jakarta: Prenada Media, 2005.

Hammâd, Nazîh. Al-'uqûud Al-Murakkabah Fî Al-Fiqh Al-Islâmy. Damaskus: Dâr al-Qalam, 2005.

Harpen, Irayana. "Kajian Akad Pembiayaan Logam Mulia Untuk Masyarakat Pada Pegadaian Syariah.” Menara Riau 13, no. 1 (2014): 39-60.

Haryono, Haryono. "Dinamika Dan Solusi Pengembangan Multi Akad (Hybrid Contract) Sebagai Basis Produk Perbankan Syariah." Ad Deenar: Jurnal Ekonomi dan Bisnis Islam 3, no. 01 (2019): 17-36.

Hendi Suhendi. Fiqih Muamalah. Jakarta: PT. Raja Grofindo Persada, 2013.

Isfandiar, Ali Amin. "ANALISIS FIQH MUAMALAH TENTANG HYBRID CONTRACT MODEL DAN PENERAPANNYA PADA LEMBAGA KEUANGAN SYARIAH." JURNAL PENELITIAN 10, no. 2 (March 26, 2014). http://ejournal.iainpekalongan.ac.id/index.php/Penelitian/article/view/361/570.

Lexy j Moleong. Metodologi Penelitian Kualitatif. Bandung: PT. Remaja. Rosdakarya, 2006.

Maulana, Hasanudin. "Multiakad Dalam Transaksi Syariah Kontemporer Pada Lembaga Keuangan Syariah Di Indonesia.” Al-Iqtishad: Journal of Islamic Economics 3, no. 1 (2016).

Mihajat, Muhammad Iman Sastra. "Hybrid Contract In Islamic Banking and Finance: A Proposed Shariah Principles and Parameters for Product Development." EBJM - Special Issue: Islamic Management and Business 2, no. 2 (2014): 89-100.

Munif, Nasrulloh Ali. "Analisis Akad Ijarah Muntahiya Bittamlik Dalam Perspektif Hukum Islam Dan Hukum Postif DI Indonesia.” Ahkam: Jurnal Hukum Islam 4, no. 1 (July 1, 2016). http://ejournal.iain-tulungagung.ac.id/index.php/ahkam/article/view/329. 
Najamuddin. “Al-'Uqûd Al-Murakkabah Dalam Perspektif Ekonomi Syariah.” Syari'ah 2, no. 2 (2013): 5-17.

Putri Muthi'ah Mairo. "Penerapan Multi Akad Pada Beberapa Produk Lembaga Keuangan Syariah Ditinjau Dari Hukum Islam." Universitas Airlangga, 2013. http://repository.unair.ac.id/36993/.

RI, Departemen. Al-Qur'an Dan Terjemahannya. Jakarta: Darus Sunnah, 2002.

Yarmunida, Miti, Dosen Fakultas, Bisnis Islam, and Iain Bengkulu. "Penetapan Nisbah Bagi Hasil Pada Akad Kerjasama Pemeliharaan Hewan Ternak Perspektif Ekonomi Syariah.” Jurnal BAABU AL-ILMI: Ekonomi dan Perbankan Syariah 1, no. 1 (2016): 69-87. https://ejournal.iainbengkulu.ac.id/index.php/alilmi/article/view/851/727.

Yulianti, Rahmani Timorita. “Asas-Asas Perjanjian (Akad) Dalam Hukum Kontrak Syari'ah.” La_Riba 2, no. 1 (2008): 91-107. 